\title{
INVESTIGACIÓN
}

\section{Effect of phenolic extracts on trans fatty acid formation during frying}

\author{
By T.H. Gamel ${ }^{1}$, A. Kiritsakis ${ }^{2 *}$ and Ch. Petrakis ${ }^{3}$ \\ 1 Department of Food Technology, Faculty of Agriculture, Alexandria University, Egypt. \\ 2 Department of Food Technology, Technological Educational Institute, Thessaloniki, Greece. \\ 3 Mediterranean Agronomic Institute of Chania, Greece.
}

\section{RESUMEN}

Efecto de extractos fenólicos en la formación de ácidos grasos trans durante la fritura.

Aceite de oliva (mezcla de virgen y refinado) y aceite de girasol con extractos fenólicos de romero seco y aguas de vegetación de aceituna, o con el antioxidante sintético BHA en combinación con los extractos, se usaron en proceso de fritura. Se realizaron 8 operaciones de fritura a $180^{\circ} \mathrm{C}$ con intervalos de $24 \mathrm{~h}$. Se determinaron los ácidos grasos trans (TFA) por cromatografía de gases en columna capilar (CC-GC). Los ácidos grasos trans de oleico y linoleico aumentaron con el tiempo de fritura en las muestras de aceite control. Los extractos de romero, solos y en combinación con BHA, disminuyeron los niveles de ácidos grasos trans (principalmente ácido elaidico) mientras que la adicción de aguas de vegetación de aceituna no tuvo ningún efecto.

PALABRAS-CLAVE: Aceite de girasol - Aceite de oliva - Acidos grasos trans - Extracto fenólico - Fritura.

\section{SUMMARY}

Effect of phenolic extracts on trans fatty acid formation during frying.

Olive oil (blend of refined and virgin) and sunflower oil containing added methanol phenolic extracts of dry rosemary and olive vegetable water or the synthetic antioxidant BHA in combination with the extracts, were used in a frying process. Eight frying operations were performed at $180^{\circ} \mathrm{C}$ with $24 \mathrm{hr}$ intervals between fryings. During the frying period the trans fatty acids (TFA) by capillary column gas chromatography (CC-GC) were determined. Trans fatty acids of oleic and linoleic were increased with frying time in both the control oil samples. The rosemary additives (extracts) alone and in combination with BHA decreased the level of trans fatty acids (mainly elaidic acid), while the addition of olive vegetable water did not have any effect.

KEY-WORDS: Frying - Olive oil - Phenolic extract - Sunflower oil - Trans fatty acids.

\section{INTRODUCTION}

Frying is one of the oldest and most popular culinary techniques in food preparation. The substrate affects the frying oil in different ways during frying (Fedeli, 1998; Pokorny, 1998; Nawar, 1998). The oxidation of frying oil may be inhibited by the containing antioxidants (Boskou, 1998; Fedeli, 1998) or by the antioxidants present in the fried plant foods or added with spices (Pokorny, 1998). Sunflower oil is used as a frying media all over the world. Olive oil however, is commonly used as a frying media in the Mediterranean countries due to the high production in these countries (Kiritsakis, 1999). According to Rossell (1998), olive oil is a premium frying oil. It conferes stability to the food and in the mean time offers the insertion of valuable fatty acids such as monounsaturated (Fedeli, 1998).

During the frying process, the oil is continuously or repeatedly used at elevated temperatures in the presence of air. Thus, both thermal and oxidative decomposition of the oil may take place (Chang et al., 1978, Pokorny, 1998, Nawar, 1998). Advanced oxidation, due to high frying results in the formation of trans fatty acids (Kiritsakis et al., 1989; Ovesen et al., 1998). Kiritsakis et al., (1989) reported that olive oil showed the least trans isomerization among the corn oil, sunflower oil, safflower oil and partially hydrogenated vegetable oil.

The purpose of this work was to study the effect of rosemary and vegetable water methanol phenolic extracts on the formation of trans fatty acid in olive oil (a blend of refined and virgin olive oil, 3/1) and sunflower oil, during frying. The synthetic antioxidant $\mathrm{BHA}$, in combination with the methanol phenolic extracts, was also tested.

\section{EXPERIMENTAL PART}

\subsection{Preparation of Rosemary and Vegetable Water Additives (Extracts)}

Rosemary leaves were collected from the garden of the Mediterranean Agronomic Institute of Chania (MAICh) and the rosemary methanol extracts were prepared according to the method proposed by $\mathrm{Wu}$ et al., (1982). The vegetable water was obtained 
from the Institute of Subtropical and Olive Trees of Chania. The methanol phenolic extracts were prepared by using the method of Balice and Cera (1984).

\subsection{Oils-Additives}

Blend olive oil (mixture of refined and virgin 3 to 1 ) was used. The methanol phenolic extracts were added in the following concentrations and combinations: $200 \mathrm{ppm}$ rosemary extract, $200 \mathrm{ppm}$ vegetable water extract, $100 \mathrm{ppm}$ rosemary extract $+100 \mathrm{ppm} \mathrm{BHA}$, $100 \mathrm{ppm}$ vegetable water extract $+100 \mathrm{ppm} \mathrm{BHA}$.

\subsection{Frying Studies}

For the frying studies, $350 \mathrm{~g}$ of potatoes were fried in $900 \mathrm{~g}$ oil samples at $180^{\circ} \mathrm{C}$ for $15 \mathrm{~min}$. The oil was used 8 times. At each sampling $30 \mathrm{~g}$ of oil was taken for fatty acids and trans fatty acids analysis (Off. Journal of European Comun., 1991).

\subsection{Fatty Acid Analysis}

$0.5 \mathrm{~g}$ of the oil sample was weighed in a glass vial, $0.3 \mathrm{~g}$ (approximately $0.4 \mathrm{ml}$ ) of sodium methylate solution was added, the vial closed well and immersed in a water bath at $85^{\circ} \mathrm{C}$ to $90{ }^{\circ} \mathrm{C}$ for two hours being shaked, from time to time, to accelerate the reaction. The esterification process was completed when the contents of the vial were clear after sedimentation of the glycerine and the residue of the reagents. After cooling, $1 \mu \mathrm{l}$ of the fatty acid methyl ester sample was injected for analysis into a high resolution gas chromatography Hewlett Packard 5890 series II equipped with a flame ionization detector (FID), and a capillary column (FFAP $50 \mathrm{~m} \times 0.2 \mathrm{~mm}$ id $x 0.33 \mu \mathrm{m}$ thickness) with the following conditions: Split ratio 1: 70 , Head pressure: 30 psi, Carrier gas flow rate: He $37 \mathrm{ml} / \mathrm{min}$, Column temperature: $225^{\circ} \mathrm{C}$, Injector temperature: $250{ }^{\circ} \mathrm{C}$, Oven temperature: $220{ }^{\circ} \mathrm{C}$, Detector temperature: $280^{\circ} \mathrm{C}$.

After fatty acid analysis, the ratio of unsaturated / saturated fatty acids was determined.

\subsection{Trans Fatty Acids Determination}

A quantity of $0.5 \mu \mathrm{l}$ of the methylated fatty acids was injected into the gas chromatograph using flame ionization detector (FID) and capillary column (BPX $7050 \mathrm{~m} \times 0.22 \mathrm{~mm}$ id $\times 0.25 \mu \mathrm{m}$ thickness). The following conditions were applied: Split ratio 1: 80 , Head pressure: $30 \mathrm{psi}$, Carrier gas flow rate: He $37 \mathrm{ml} / \mathrm{min}$, Column temperature: $225^{\circ} \mathrm{C}$, Injector temperature: $250^{\circ} \mathrm{C}$, Oven temperature: $165^{\circ} \mathrm{C}$ (5 min) -[increase by $\left.2{ }^{\circ} \mathrm{C} / \mathrm{min}\right]-220^{\circ} \mathrm{C}(5 \mathrm{~min})$, Detector temperature: $280^{\circ} \mathrm{C}$.

\section{STATISTICAL ANALYSIS}

The Statistical analysis was carried out using the LSD test and DUNCAN's Multiple Range test to evaluate the significant difference between the samples.

\section{RESULTS AND DISCUSSION}

\subsection{Effect of Phenolic Extracts on Unsaturated to Saturated Fatty Acids Ratio During Frying}

The initial unsaturated to saturated fatty acid ratio (oleic acid + linoleic acid / palmitic acid + stearic acid) for the blend olive oil was 5.91. After the $8^{\text {th }}$ frying the value ranged from 5.83 to 5.80 for the samples containing additives and for the control. However, the initial ratio of unsaturated/saturated fatty acids for the sunflower oil was higher (8.30) than olive oil (5.91) due to the high amount of unsaturated fatty acids and to the low amount of saturated fatty acids present in sunflower oil (Kiritsakis, 1998). At the end of the experiment, in sunflower oil, the value of unsaturated to saturated fatty acids ranged from 8.00 to 8.10 for the samples containing additives and for the control. Thus, no significant change in this ratio for both the oils and for all the samples containing additives was observed. Indeed, the percentage of oleic and linoleic acids decreased no significantly with the time of frying. Also the percentage of saturated fatty acids, such as palmitic and stearic acids increased lightly.

Although a significant decrease of the unsaturated to saturated fatty acids ratio was not found, occurrence of oxidation products should not be disregarded since the peroxide value (data not presented) of all the samples was increased and then decreased due to the decomposition caused by the frying temperature, indicating that samples were oxidized. Our results showed the low sensitivity of the method determining the ratio of unsaturated to saturated fatty acids and come in agreement with others (Cuesta et al., 1991). Probably this particular ratio does not change until substantial alteration is achieved.

\subsection{Effect of Phenolic Extracts on the Formation of Trans Fatty Acids During Frying}

\subsubsection{Trans Oleic Acid (Elaidic)}

Tables I and II show an increase of the trans oleic acid (elaidic acid) content in both oils due to frying, which results in thermal oxidation (Kiritsakis et al., 1989; Warner y Knowlton, 1997; Cuesta y Sánchez-Muniz, 1998; Pantzaris, 1998). Trans-oleic 
acid content increased for blend olive oil from $0.045 \%$ to $0.082 \%$ (Table I) and for sunflower oil from $0.025 \%$ to $0.070 \%$ (Table II). A significant difference in the trans oleic acid content between the control sample and the samples containing phenolic additives was observed. After the $8^{\text {th }}$ frying, samples with 100 ppm rosemary extract +100 ppm BHA and those with $200 \mathrm{ppm}$ rosemary extract contained lower percentage of trans-oleic acid than the control in both oils (Tables I, II). This was attributed to the antioxidant effect of the additives which prevented oxidation and further more trans isomerization.

Table I

Effect of the frying process on the formation of trans-oleic acid in blend olive oil containing added phenolic extracts and the antioxidant BHA

\begin{tabular}{|c|c|c|c|c|c|}
\hline \multirow{3}{*}{ Treatments } & \multicolumn{5}{|c|}{ Trans Oleic Acid (\%) } \\
\hline & \multicolumn{5}{|c|}{ Number of Fryings } \\
\hline & 0 & 2 & 4 & 6 & 8 \\
\hline Olol Control & $0.045 a$ & $0.052 a b$ & $0.063 \mathrm{bc}$ & $0.068 \mathrm{c}$ & $0.082 \mathrm{~d}$ \\
\hline Olol + 100 ppm Vw + 100 ppm BHA & $0.045 a$ & $0.048 a$ & $0.049 \mathrm{ab}$ & $0.061 \mathrm{~b}$ & $0.069 c$ \\
\hline Olol + 200 ppm Vw & $0.045 a$ & $0.048 a$ & $0.056 a b$ & $0.058 b$ & $0.065 b c$ \\
\hline Olol + 100 ppm Ros + 100 ppm BHA & $0.045 a$ & $0.042 a$ & $0.048 \mathrm{ab}$ & $0.055 \mathrm{ab}$ & $0.061 b$ \\
\hline Olol + 200 ppm Ros & $0.045 a$ & $0.043 a$ & $0.053 a b$ & $0.060 \mathrm{~b}$ & $0.063 b c$ \\
\hline
\end{tabular}

Olol = Blend of refined and virgin olive oil $(3 / 1), V w=$ Vegetable Water extract, Ros $=$ Rosemary extract.

Values with the same letter are not significantly different, with Duncan's Multiple Range Test.

Table II

Effect of the frying process on the formation of trans-oleic acid in sunflower oil containing added phenolic extracts and the antioxidant BHA

\begin{tabular}{|c|c|c|c|c|c|}
\hline \multirow{3}{*}{ Treatments } & \multicolumn{5}{|c|}{ Trans Oleic Acid (\%) } \\
\hline & \multicolumn{5}{|c|}{ Number of Fryings } \\
\hline & 0 & 2 & 4 & 6 & 8 \\
\hline Sfo Control & $0.025 a$ & $0.047 \mathrm{bc}$ & $0.052 \mathrm{c}$ & $0.068 d$ & $0.070 d$ \\
\hline Sfo +100 ppm Vw + 100 ppm BHA & $0.025 a$ & $0.044 b$ & $0.049 c$ & $0.067 d$ & $0.069 d$ \\
\hline Sfo $+200 \mathrm{ppm} \mathrm{Vw}$ & $0.025 a$ & $0.043 b$ & $0.047 \mathrm{bc}$ & $0.064 d$ & $0.064 d$ \\
\hline Sfo + 100 ppm Ros + 100 ppm BHA & $0.025 a$ & $0.44 b$ & $0.044 b$ & $0.060 \mathrm{~cd}$ & $0.060 \mathrm{~cd}$ \\
\hline Sfo +200 ppm Ros & $0.025 a$ & $0.032 a$ & $0.043 b$ & $0.051 \mathrm{c}$ & $0.056 \mathrm{c}$ \\
\hline
\end{tabular}

Sfo $=$ Sunflower oil, $\mathrm{V} w=$ Vegetable Water extract, Ros $=$ Rosemary extract.

Values with the same letter are not significantly different, with Duncan's Multiple Range Test.

\subsubsection{Trans-Linoleic Acid}

The formation of trans-linoleic acid in both oils during frying is shown in Tables III and IV: Sunflower oil (Table IV), contained significantly higher percentage of trans-linoleic acid than olive oil at the end of frying. Trans-linoleic acid content increased from $0.123 \%$ to $0.144 \%$ (Table III) and from $0.425 \%$ to $0.440 \%$ (Table IV) in the control samples of blend olive oil and sunflower oil, respectively. This was attributed to the higher amount of linoleic acid in sunflower oil than in olive oil (Kiritsakis, 1998). Generally, a small increase in the trans-linoleic acid in the two control oil samples and those containing the additives was observed. Thus, no there was not indication for the effect of phenolic extracts on preventing trans-linoleic acid formation during the frying process. 
Table III

Effect of the frying process on the formation of trans-linoleic acid in blend olive oil containing added phenolic extracts and the antioxidant BHA

\begin{tabular}{lccccc}
\hline & \multicolumn{4}{c}{ Trans Linoleic Acid (\%) } \\
\cline { 2 - 6 } & \multicolumn{3}{c}{ Treatments } & \multicolumn{3}{c}{ Number of Fryings } \\
\cline { 2 - 6 } & 0 & 2 & 4 & 6 & 8 \\
\hline Olol Control & $0.123 \mathrm{a}$ & $0.129 \mathrm{ab}$ & $0.139 \mathrm{~b}$ & $0.141 \mathrm{~b}$ & $0.144 \mathrm{bc}$ \\
Olol + $100 \mathrm{ppm} \mathrm{Vw}+100 \mathrm{ppm}$ BHA & $0.123 \mathrm{a}$ & $0.128 \mathrm{ab}$ & $0.133 \mathrm{~b}$ & $0.140 \mathrm{~b}$ & $0.142 \mathrm{~b}$ \\
Olol + $200 \mathrm{ppm} \mathrm{Vw}$ & $0.123 \mathrm{a}$ & $0.125 \mathrm{a}$ & $0.120 \mathrm{a}$ & $0.127 \mathrm{ab}$ & $0.129 \mathrm{ab}$ \\
Olol + $100 \mathrm{ppm}$ Ros + $100 \mathrm{ppm}$ BHA & $0.123 \mathrm{a}$ & $0.123 \mathrm{a}$ & $0.123 \mathrm{a}$ & $0.125 \mathrm{a}$ & $0.127 \mathrm{ab}$ \\
Olol + $200 \mathrm{ppm}$ Ros & $0.123 \mathrm{a}$ & $0.125 \mathrm{a}$ & $0.125 \mathrm{a}$ & $0.127 \mathrm{ab}$ & $0.129 \mathrm{ab}$ \\
\hline
\end{tabular}

See Table I for abbreviations.

Values with the same letter are not significantly different, with Duncan's Multiple Range Test.

Table IV

Effect of the frying process on the formation of trans-linoleic acid in sunflower oil containing added phenolic extracts and the antioxidant BHA

\begin{tabular}{|c|c|c|c|c|c|}
\hline \multirow{3}{*}{ Treatments } & \multicolumn{5}{|c|}{ Trans Linoleic Acid (\%) } \\
\hline & \multicolumn{5}{|c|}{ Number of Fryings } \\
\hline & 0 & 2 & 4 & 6 & 8 \\
\hline Sfo Control & $0.425 a$ & $0.427 a$ & $0.429 a$ & $0.437 \mathrm{~b}$ & $0.440 \mathrm{~b}$ \\
\hline Sfo $+100 \mathrm{ppm} \mathrm{Vw}+100$ ppm BHA & $0.425 a$ & $0.427 a$ & $0.430 a$ & $0.446 \mathrm{bc}$ & $0.446 \mathrm{bc}$ \\
\hline Sfo $+200 \mathrm{ppm} \mathrm{Vw}$ & $0.425 a$ & $0.430 \mathrm{a}$ & $0.432 a$ & $0.437 a b$ & $0.440 \mathrm{~b}$ \\
\hline Sfo $+100 \mathrm{ppm}$ Ros +100 ppm BHA & $0.425 a$ & $0.425 a$ & $0.462 a$ & $0.426 a$ & $0.426 a$ \\
\hline Sfo +200 ppm Ros & $0.425 a$ & $0.430 a$ & $0.431 a$ & $0.431 a$ & $0.432 a$ \\
\hline
\end{tabular}

See Table II for abbreviations.

Values with the same letter are not significantly different, with Duncan's Multiple Range Test.

\subsubsection{Trans-Linolenic Acid}

Trans-linolenic was formed in a very low amount (less than $0.002 \%$ ). Data are not presented.

In conclusion, our results showed that blend olive oil was more resistant to trans fatty acid formation during the frying process. The addition of rosemary extract especially at the concentration of $200 \mathrm{ppm}$ and the combination of $100 \mathrm{ppm}$ rosemary extract +100 ppm BHA decreased, significantly, the formation of trans oleic acid in both oils. Vegetable water extract was found to have a very low effect on preventing trans fatty acid formation in fried oils.

\section{ACKNOWLEDGEMENTS}

We acknowledge Mr. A. Nikolaidis, director of the Mediterranean Agron. Institute of Chania (MAICh), Greece, where this work was conducted.

\section{BIBLIOGRAPHY}

Balice, V. y Cera, O. (1984).- - «Acidic phenolic fraction of the olive vegetation water determined by a gas chromatographic method".-Grasas y Aceites, 35, 178-180. 
Boskou, D. (1998).- «Frying temperatures and minor constituents of oils and fats".-Grasas y Aceites, 49, 326-330.

Chang, S. S., Peterson, J. R. y Ho, C. (1978).- «Chemical reactions involved in the deep-fat frying of foods".- J Am Oil Chem. Soc, 55, 728-727.

Cuesta, C. y Sánchez-Muniz, F.J. (1998).- «Quality control during repeated frying".-Grasas y Aceites, 49, 310-318.

Cuesta, C., Sánchez-Muniz, F. J. y Fernández, I. (1991).«Evaluation of nonpolar methyl esters by column and gas chromatography for the assessment of used frying olive oils".-J Am. Oil Chem. Soc., 68, 443-445.

Fedeli, E. (1998).— «Physical-chemical aspects of the frying process".-Grasas y Aceites, 49, 261-264.

Kiritsakis, A. (1999).- «Olive oil: The right choice».-(In Press).

Kiritsakis, A. (1998).- - Olive oil: From the tree to the table».-2 $2^{\text {nd }}$ Ed, Food and Nutrition Press, Inc, Trumbull (Conn), USA.

Kiritsakis, A., Aspris, P. y Markakis, P. (1989).- «Trans isomerization of certain vegetable oils during frying". Flavors and Off-Flavors. G. Charalambous, (Ed). Proceeding of the $6^{\text {th }}$ International Flavor Conf. Rethymnon, Crete, Greece.

Nawar, W. W. (1998). - «Volatile components of the frying process".-Grasas y Aceites, 49, 271-274.
Official Journal of the European Communities (1991).N. ${ }^{\circ} 1.248 / 45$.

Ovesen, L., Leth, T. y Hansen, K. (1998)._- «Fatty acid composition and contents of trans monounsaturated fatty acids in frying fats and in margarines and shortening marketed in Denmark».-J. Am. Oil Chem. Soc., 75, 1079-1083.

Pantzaris, T. P. (1998).- «Comparison of monounsaturated and polyunsaturated oils in continous frying".Grasas y Aceites, 49, 319-325.

Pokorny, J. (1998).- «Substrate influence on the frying process".-Grasas y Aceites, 49, 265-270.

Rossel, J. B. (1998). - «Industrial frying process».Grasas y Aceites, 49, 282-295.

Warner, K. y Knowlton, S. (1997)._- «Frying quality and oxidative stability of high-oleic corn oils".-J Am. Oil Chem. Soc., 74, 1317-1322.

Wu, J. W., Lee, H., Ho, C. T. y Chang, S. S. (1982)."Elucidation of the chemical structure of natural antioxidants isolated from Rosemary".-J. Am. Oil Chem. Soc, 59, 339-345. 